\title{
RESILIENT MANUFACTURING: CASE STUDIES \\ IN THAI AUTOMOTIVE INDUSTRIES DURING THE COVID-19 PANDEMIC
} pages: $99-113$

\author{
NAJAVADH KAEO-TAD ${ }^{(1)}$ ChAWALIT JEENANUNTA \\ KWANCHANOK CHUMNUMPORN \\ THANAPATRA NITISAHAKUL VARARAT SANPRASERT
}

\begin{abstract}
A B S T R A C T
The coronavirus pandemic is a crisis that disrupts the global supply chain and slows down the world economy. A significant challenge for the companies in the manufacturing sector is to mitigate risks related to the COVID-19 outbreak. Grounded in the resilience theory, resilience (i.e., prepare, prevent, protect, respond, and recover processes) aims to manage risks and ensure business continuity. This research aims to identify the key factors for the resilient manufacturing management of Thai automotive industries during the COVID-19 outbreak. Three outstanding companies of tier 1 automotive suppliers have been selected as case studies in this work. This qualitative research was completed by using a semi-structured interview. The target interviewers were CEOs or general managers. The data analysis was divided into two phases. Phase one summarised the interview data of each company. Phase two used thematic analysis and cross-case analysis to identify resilience practices' patterns, themes, and multi-factors. The findings indicate three key factors to enhance resilience: leadership, technology, and the firm's experience in handling emerging events. Together, these factors help enterprises to prepare for Business Continuity Planning (BCP), improve supply chain management, and increase the firm's ability to recover from disruption situations. This paper contributes to the literature on the supply chain resilience in the automotive industry by providing a guideline for firms to implement resilience practices, improve business operations, and increase firm's capabilities, both as human skills and technologies, to deal with a novel crisis. Resilience practices response to the COVID-19 outbreak not only helps the companies minimise business disruption in the short-term but also includes the long-term response strategies for unknown events. For this purpose, the case study research was conducted to investigate the resilience strategies during the COVID-19 pandemic and determine the critical success factors of resilience implementation in the Thai automotive industry.
\end{abstract}

KEY WORDS

resilience, COVID-19, supply chains management, risk management, automotive industry, Business Continuity Plan

10.2478/emj-2021-0024
Chawalit Jeenanunta

Thammasat University, Thailand ORCID 0000-0002-1932-9776

Corresponding author: e-mail: chawalit@siit.tu.ac.th

Najavadh Kaeo-tad

Thammasat University, Thailand ORCID 0000-0002-2520-5593

Kwanchanok Chumnumporn

Thammasat University, Thailand ORCID 0000-0003-4429-1674

Thanapatra Nitisahakul

Thammasat University, Thailand

Vararat Sanprasert

Thammasat University, Thailand

\section{INTRODUCTION}

Resilience is an adequate ongoing action that aims to process lessons learned and prepare for unknown events. This leads the organisation to quick recovery and can create a safety net for such unex- pected situations as the coronavirus disease (COVID19), which was first identified in December 2019 in Wuhan, China. This emerging situation was declared a global pandemic on March 11, 2020, by the World Health Organization (WHO). The first confirmed

Kaeo-tad, N., Jeenanunta, Ch., Chumnumporn, K., Nitisahakul, T., \& Sanprasert, V. (2021). Resilient manufacturing: case studies in Thai automotive industries during the COVID-19 pandemic. Engineering Management in Production and Services, 13(3), 99-113. doi: 10.2478/emj-2021-0024 
case of COVID-19 was detected in Thailand on January 13, 2020 (Lai et al., 2020). The Thai government announced a strategy to contain the coronavirus pandemic, including wearing masks, social distancing, quarantine, and travel restrictions to (Namwat et al., 2020). However, the coronavirus mutations make it more challenging for the government to control the outbreak, especially with some infected people exhibiting no COVID-19 symptoms. COVID-19 triggered interventions aimed at reducing contacts between people, such as business restrictions, area lockdowns, and restricted movement of citizens. Such restrictions and policies are announced and enforced for individuals and organisations depending on the rate of infections in Thailand.

As the coronavirus can spread through the air, factories are concerned with outbreaks due to closed spaces, limited available floor area, and crowding. The clusters of COVID-19 infections in factories could have large numbers of workers, resulting in a rapid spread. The Thai government is concerned with the COVID-19 transmission in factories; therefore, policies for preventing, detecting, and controlling COVID-19 infections in factories have been introduced since the beginning of the outbreak. Critical security measures for factories established by the Centre for COVID-19 Situation Administration (CCSA), the Department of Disease Control under Ministry of Public Health, and the Federation of Thai Industries (FTI) can be summarised into three response roles of business owners/leaders, organisations, and individuals (workers). Business owners/ leaders are required to take active action and establish centres for COVID-19 protection, determine explicit rules and policies to minimise COVID-19 disruptions, and ensure that employees strictly follow the procedures. Organisations are requested to submit to the local disease control agency plans for COVID-19 prevention in the workplace. The COVID-19 prevention plan must include standard operating procedures for screening, detecting, and tracking infections. Organisations are required to develop protocols for workplace disinfection, labour travel restrictions, and quarantine in the case of confirmed COVID-19 infections. In addition, organisations are required to rearrange the working areas, working schedules, and production plans following the social distancing restrictions. Employees are at all times request to wear masks in the workplace, self-declare their health status, and follow the COVID-19 prevention procedures stringently (Centre for COVID-19 Situation Administration, 2020; Department of Disease Con- trol, 2021; Federation of Thai Industries, 2020). Interventions required to counteract the COVID-19 pandemic affected business operations and changed the way employees work. Virtual or remote work and online meetings were adopted for employees to work from home (WFH) (Gallup, 2020; Tortorella et al., 2021). The new normal is a challenge for the manufacturing and service sectors to operate, the resilience of businesses and supply chain management.

The coronavirus outbreak reduced the global economic growth in 2020, which continues to decline in 2021. Based on statistics recorded by the Thailand Automotive Institute, the total vehicle production of 2020 was 1427275 units, which is a reduction of 29 $\%$ compared to 2019. In 2020, 792146 vehicles were sold domestically, which is a decrease of $21 \%$ compared to 2021. The export unit of 2020 was 735842 vehicles, which is a decrease of $30 \%$ from 2019 (Thailand Automotive Institute, 2021a). For the first half of 2021 (January - June), the total vehicle production was 710356 vehicles, the domestic sale was 308211 vehicles, and the export amounted to 390467 units. The percentage of vehicle production, domestic sale, and export units increased by $33 \%, 14 \%$, and 30 $\%$, respectively, compared with the same period of 2020. However, the results are diminished when compared with the same period of 2019 , showing a reduction of $20 \%, 30 \%$, and $16 \%$, respectively (Thailand Automotive Institute, 2021b). In 2019, Thailand ranked first as the largest automotive producer in ASEAN, fifth in Asia, and eleventh in the world (Yongpisanphob, 2020). The decreased productivity of the Thai automotive industry producers caused by the pandemic can impact the sale of vehicles and auto parts due to the disrupted global automotive supply chain. Thus, it is essential to investigate the responses of Thai automotive suppliers to the COVID-19 disruptions to prevent the supply shortage and bring sustainability to the supply chain.

The impact of the COVID-19 pandemic is considerably different from other supply chain disruptions (i.e., earthquakes, floods, civil unrests, and terrorist attacks) in two terms: (1) magnitude - the scale and duration of the impact caused by the disruption on related enterprises; and (2) duration - the time that the impact caused by the disruption on the supply chain lasted (Guan et al., 2020; Moosavi \& Hosseini, 2021). Based on Nakamura and Managi (2020), an organisation should understand the short and long-term implications and reasonable risk assessments on a new phenomenon, such as the coronavirus epidemic. However, there is little data-driven 
evidence to guide the global supply chains in resilience practice against the COVID-19 disruptions (Yoo \& Managi, 2020).

This paper presents case studies of Thai automotive suppliers practising resilient manufacturing management in dealing with the disruption related to the COVID-19 pandemic. The article provides a conceptual framework of resilience and key success factors of resilience. The research outcome advances supply chain management research to develop a Business Continuity Planning (BCP) and adopt resilience practice used during a pandemic or any unknown situation.

The remainder of the paper is organised as follows: Section 1 provides the literature review of the relevant COVID-19 effects on business operations, new everyday procedures, the resilience definition and practices, and supply chain management. Section 2 depicts the research methodology and illustrates the structure of a semi-structured interview. Section 3 gives interview results for the three case studies. Section 4 presents thematic analysis and cross-case analysis to determine the resilience practices and key success factors, then discussing the findings. Finally, the conclusions are given.

\section{LITERATURE REVIEW}

The reduction in productivity gas been influenced by national lockdowns and restrictions in different countries. Interventions triggered by the COVID-19 pandemic disrupted the entire supply chain, especially for the automotive industry. Carmakers and distributers have suffered from disturbed domestic and international logistics services. This resulted in lower orders, insufficient materials/auto parts, increased lead time, and customer dissatisfaction. Therefore, firms need to provide resilient production plans, strengthen partnerships, and implement health-related measures to avoid outbreaks in the workplace. This research is a case study analysis that aims to determine the disruption in the supply chain of the automotive industry due to the COVID-19 pandemic.

The COVID-19 pandemic affects the production of raw materials and spare parts, failing to meet the demand because of distribution difficulties. The financing risk for small to medium-sized companies and the demand fluctuation increased (Cai \& Luo, 2020). Once faced with the pandemic, every country came up with plans to control the infection. Some research shows that the impact of the COVID-19 pandemic is decreased gradually, aiming to avoid more lockdowns. Earlier, stricter and shorter lockdowns should have been implemented to reduce the damage to global supply chains (Guan et al., 2020).

The pandemic disrupts healthcare and economics worldwide. Healthcare organisations face complications just as in other sectors. Supply chain leaders face challenges due to the loss of control over the situation. Nevertheless, leaders must continuously strategise, preparing for long-term change in the future (Francis, 2020). Required internal preparations for organisations include measures to ensure employee safety and sufficient product in stock to satisfy customer needs. Based on some estimations, it will take three years for the situation to recover. Under such uncertainties, leaders must be flexible and improvise, which requires continuous preparation (Lombardi et al., 2021). Yau et al. (2021) listed eight points for the management of the COVID-19 outbreak, which include fast identification of cases, enforcement of public health measures, external support (i.e., government), extra training and education for employees, personal protective equipment, organisational culture, executive level, cooperation, and hiring specialists to handle the pandemic.

Enterprises are challenged by the need to adapt rapidly to interventions triggered by the COVID-19 outbreak and minimise supply chain disruptions. This ongoing process can be considered a resilience cycle. The holistic approach to the resilience concept relies on technology and society. Scharte et al. (2014) developed a working definition of resilience as "the ability to repel, prepare for, take into account, absorb, recover from and adapt ever more successfully to actual or potential adverse events. Those events are either catastrophes or processes of change with the catastrophic outcome which can have human, technical or natural causes" (Scharte et al., 2014, p. 17). The National Academies Committee on Increasing National Resilience to Hazards and Disasters defined resilience as "the ability to prepare and plan for, absorb, recover from or more successfully adapt to actual or potential adverse events" (The National Academies 2012, p. 14). Resilience can be divided into five stages, i.e., prepare, prevent, protect, respond, and recover. The stages aim to prepare the enterprises for actual or potential adverse events. Practically implemented resilience can help enterprises advance, prepare and plan for emerging situations, cope with and recover from disasters or change processes. In 
preparation, enterprises also continuously improve their ability to adapt to adverse events.

The way the whole organisation works also changed a lot during the pandemic. Employees need to follow strict regulations to prevent infection; work patterns and routines had to be revised. Firms had to adopt Industry 4.0 technologies and synchronise them with earlier solutions. This will increase production efficiency and help to alleviate the COVID19 effect (Narayanamurthy \& Tortorella, 2021). Production lines were automated. An important role in the automotive system is played by Big Data Analytics, tracking real-time information on supply chain activities to overcome the obstacles that need a high level of cooperation among stakeholders (Belhadi et al., 2021). Firms need to consider solutions they might be hesitant to use to limit the virus. Artificial intelligence (AI) and robots have been implemented by early adopters in the industry, and the idea should be considered for overcoming the crisis. Telecommuting and flexible work were applied worldwide to continue business activities without an increased risk of infection.

With the pandemic drawing towards the end, the old normal might return since the crisis may have permanently changed the way people do business. Some technologies already existed before the pandemic, but it became the factor that led to forced adoption aiming to survive (Heidenreich \& Talke, 2020; Giones et al., 2020). Barriers to using technologies were broken by many users. Even though physical meetings will be brought back after the virus is eliminated, the technology will still offer an option that reduces travel costs and is less time-consuming (Brem et al., 2021). However, some challenges need to be considered while using technologies, including security, privacy, biases, ethics, and the digital divide (He et al., 2021).

The COVID-19 pandemic was unexpected and very unusual. Such situations are rare and dissimilar to other crises, which make them difficult to resolve, requiring an exclusive new strategy and plan for advance response to the health disaster and the allocation of resources, financial as well as human, with the latter requiring training and education to avoid a surge in infection cases (Peleg et al., 2021). Evidence suggests that Business Continuity Planning (BCP) had a significant influence on the supply chain (Ishida, 2020). Business Continuity Plans have been used by medium and large companies for a long time, especially those associated with foreign companies. However, since the expansion of COVID-19, Busi- ness Continuity Plans have proved crucial for every company, including small, as they also faced difficulties related to the pandemic (Margherita \& Heikkilä, 2021).

Supply chain risk management and production chain performance have significant links worldwide and relationships between stakeholders and partners. Minimising risks enables firms to generate long-term benefits to all stakeholders and build a competitive position, particularly in such a confounded and moderately developing industry as the automotive industry. Globally, some most significant segments of the industry, including traveller and business vehicles, were estimated to decrease to 59.5 million units in 2020 from an optimal number of 79.6 million units in 2017. To understand the related threats and issues faced by the industry, the analysis must focus on Supply Chain Relationship Management, which should be organised to oversee everyday practice and extraordinary dangers, such as economic crises, worldwide pandemics, or other unexpected situations. Risks should be addressed carefully and responsively, checking client's requirements, changes in the chain, suppliers and competitors, technology improvements and systems to proactively recognise risks and empower the speediness of response to events, engaging in activities that allow avoiding or reducing possible effects. The essential Supply Chain Relationship Management measure comprises defining, assessing, mitigating, and monitoring hazards in the supply chain (Yoga Irsyadillah \& Dadang, 2020). The risk management process requires understanding how the key enablers influence the process and how to utilise them effectively; the key enablers include flexibility, organisational learning, information systems, and performance metrics (Manuj \& Mentzer, 2008).

Finally, even though companies are currently countering the effects of the COVID-19 pandemic, they still think beyond and make additional preparations for the post-crisis period to recover from the losses gained since the pandemic hit the industry (Cai \& Luo, 2020).

\section{RESEARCH METHODS}

The qualitative research was done using a semistructured interview from December 2020 until May 2021. CEOs and top managers from three automotive firms of Tier 1 shared information and experience 
and discussed the effects of the COVID-19 pandemic and solutions.

Questions are formulated as a guideline, and additional questions were asked to clarify specific topics with more explanations. The questions were mainly open-ended, aiming to collect detailed information and analyse viewpoints on a particular part of the questions. The flexibility of the conversation resulted in a variety of answers. Examples of questions allowed interviewees to prepare detailed answers and ensure their reliability.

Personal interviews allowed learning in greater detail how companies went through business difficulties during the pandemic period. Due to governmentimposed restrictions, some of the interviews were managed via an online meeting program, e.g., Google Meet, Microsoft Teams or Zoom. Below, an example of interview questions is shown.

- Has your organisation established policies for the prevention and management of COVID-19 cases? When was the first policy published, and did something change?

- Have there been any changes in the production after the COVID-19 outbreak, especially in the part of the rubber system?

- Have there been any changes in the communication of the firm, and if yes, what did you change? Which part of the organisation is currently using the "new normal" approach?

- In the case of the necessity to travel to an area hit by an epidemic, what strategies will you apply?

- Were any changes implemented during the first and second waves of the COVID-19 pandemic? In the case of changes introduced during the second wave, please briefly elaborate on the differences between the measures taken during the first and second waves.

- How is the organisation dealing with procurement and manages products in stock?

The analysis used the thematic method to identify the key factors. A cross-case analysis was associated with the broad topic of similarities and differences among all the cases. First, detailed information was collected for each case. Topics were determined to cluster findings into categories. When the association between the cases was found, the explanation and supporting evidence were formed to probe the relationship between the cases. Once the data was collected and organised into categories, the general direction was found in procedures used by the companies to handle the situation. The themes were divided into several topics of interest to conclude and combine key success factors for dealing with the COVID-19 pandemic. The information can be used as a guideline to manage a pandemic disruption that might occur in the future.

\section{RESEARCH RESULTS}

\subsection{Company A}

Company A was first registered as a limited company in May 1980. It was founded by a Thai and Japanese joint venture. In May 1991, it was listed on the Stock Exchange of Thailand. The vision of the company reads, "by daring to outshine light, we will pave our path to a bright future". The products include automotive lightning products (headlamp, fog lamps, rear combination lamp, solar radiation sensors, and auto-levelling unit), motorcycle lighting products (head combination lamp, rear combination lamp), auto bulb products and dies \& moulds.

The deputy director and managers from related departments were interviewed in the middle of December 2020. The first COVID-19 prevention measure was introduced in February 2020 and consisted of checking every person before entering the factory. Also, alcohol gel was provided for people to use. Employees from high-risk areas with a high rate of infection had to quarantine. Space for employees to work and the dining area were limited, so different break times for employees were introduced to reduce crowding. Visitors and had to wear three layers of medical masks (fabric masks were not allowed).

The highest sales of the company were in 2019, but since the start of the COVID-19 pandemic, sales dropped to around $40 \%$. All measures had to be taken inside the organisation. In cases of no available work, employees were asked to stay at home. Online conferences were introduced instead of face-to-face meetings with employees working abroad. The company stated having had no problems with outsourcing or milk run. KPI was still around the same, and the company wanted to stock more, but the supplier could not send the product due to a container shortage. Also, shipping was taking longer than before.

The company did more training for employees who were less involved in production. The Human Resources Department changed some of the training procedures and methods. In addition, all of the delivered products were spayed to ensure their safety. 


\subsection{Company B}

Company B has been in the market for 60 years, supplying parts and components for high-end international automotive brands. About 2000 employees work in the factory producing four categories of products, including parts and spare parts, OEM, Ground Support Equipment (GSE), and Logistics Solutions, participating at every level of the supply chain. The company has plants overseas and cooperates with foreign companies. It has been awarded many International Standardisation and Organisation certificates and gained much trust from other automotive brand partners. Fast improvements of the company result from being a supplier for foreign companies implementing technology transfer and auditing practise of 30 years. In its long history, the company has encountered many unexpected problems that can affect a business, e.g., the Thailand Tom Yum Kung crisis or flood in 2011. Consequently, it has a robust plan to manage such situations. Recently, the company started a cooperation with government organisations and educational institutions to develop electric vehicle technology.

The general manager of the department tasked with human capital development and organisation was interviewed at the end of March 2021. The company announced the COVID-19 prevention measures after the board committee meeting, which appointed the director to deal with the COVID-19 situation. Rules were established, including shift work for employees in manufacturing. Some departments applied to work from home. The organisation equipped a kitchen for cooking food and other necessary tools for the period of the country's lockdown. Visits were allowed only for suppliers and customers who could not conduct matters online. Strict COVID19 prevention rules were applied in such cases. Employees were not allowed to visit the "red zone" during the holiday period, and violators risked disciplinary measures. Employees who needed to visit the "red zone" had to self-isolate and undertake a swab test for a medical statement before coming back to work. The company also developed a mobile application for employees to train them in using smartphones as primary internal communication devices. The research and development department conducted supply and procurement tasks using online channels. Technology support was provided by the government agency, science organisation, and university.

Only some departments could work from home, but the production process still needed technicians to control the machines. Most companies have no technology to remotely control the machines yet. The company can provide the device, e.g., a computer, but other problems, such as Internet access, require more investments. Most factories followed routine procedures.

For the manufacturing part, the supply chain was disrupted entirely. Some imported parts faced difficulties with orders. Due to the COVID-19 outbreak, the lead time increased by 14-15 days for China and increased the lot sizes for import products. The domestically sourced parts and products did not encounter many changes. In the middle of 2020, no export overseas was possible as almost all factories temporarily closed for several months. However, for some domestic suppliers and customers, sales were still possible. The situation in the industry is complicated. In the worst-case scenario, the company has to leave the industry. The first case was discovered in Thailand almost five months before the company recovered in the mid of 2020 . The situation seemed to be getting better in 2021 .

Once the situation improved, the company still faced problems because cargo ships and containers were difficult to access due to the rising demand. The prices increased, and advanced bookings were required. Sometimes, shipments were delayed, and the production and delivery had to be postponed. The company needed to work harder than usual.

Communications with suppliers and customers mostly moved online. Only necessary appointments were allowed in the factory. Regular visits, such as for education, were stopped. Meetings were conducted using online meeting applications. Delivered products were screened before entering the premises. To ensure quality control (QC), customers usually visit plants physically. During the pandemic, the visit had to be reduced from four times to two times/year. To ensure the safety and quality of products, some customer visits were still allowed, or products were sent to customers for QC and discussions held online.

For more than a year, no meetings in person between suppliers were arranged. With some countries restricting travel and requiring a fourteen-day quarantine, suppliers and customers agreed to online contacts to ensure safety. Therefore, no problems occurred in the relationships.

The company had a Business Continuity Plan (BCP) in place since before the pandemic spread to Thailand. The BCP was audited annually to test the company's readiness. The auditing experience of the company amounts to 30 years. Many successful plans 
were implemented by the company in the past, such as moving the plant to the gateway to be close to their customers and reduce risks. Currently, the company has an evacuation plan for a COVID-19 outbreak in the factory.

\subsection{Company C}

Company $\mathrm{C}$ started as an automotive replacement parts manufacturer and continued expanding to the production of body parts, and eventually became a vertically integrated company with worldclass manufacturing standards. Their customers are in Tier 1/2/3 Japanese automotive brands (both foreign and domestics). The company has about 800 employees. The products include plastic injection parts, lamp and mirror parts, metal standing parts, coolant parts, suspension parts, engine and brake parts, and cables and hoses. Company provided services include product design, prototype, mould design, and making and C/F, plastic injection moulding, plastic chrome plating, and plastic painting finishing and assembly.

The sustainability manager was interviewed at the beginning of May 2021. The company cooperates with Toyota as the first and second-tier supplier. It must report to Toyota monthly, with weekly supervisor visits and daily headmen checks. After the first wave of the pandemic, once the situation improved, the company exported to more than 120 countries. There is less competition for OEM and REM markets, and the company is the only company in Middle East Asia.

Discussing the manufacturing part, the respondent said that the COVID-19pandemic might be a catalyst for further development. Suppliers from China had to be replaced with partners from other countries. Fortunately, this became an opportunity to grow into the leading domestic supplier. Company $\mathrm{C}$ tried to source domestic raw materials as much as possible to continue with previous orders and fulfil new orders. It faced a reduction in export of $11 \%$ but grew by $5 \%$ domestically. The company had to deal with skyrocketing costs of shipping and containers in the fourth quarter, which increased from 30 to 500 per cent. The company had to negotiate with customers the increase in product prices due to more expensive raw materials. The company expanded their customers from B2B to B2C by launching a new 3D printing service. The majority of $\mathrm{B} 2 \mathrm{C}$ customers ordered luxury brand parts (i.e., Porsche decoration parts).
Company $\mathrm{C}$ used an application for tracking employees restricted from entering "red zones". If someone accidentally went to such an area, the company required to follow a protocol, i.e., for the employee to be swabbed, quarantined, isolated, and interviewed. The pandemic in Thailand can be separated empirically into three phases. During the first phase, Company C lost many orders from global and domestic customers because more than 700 companies and partnerships closed down. The revenue remained high, but the gross profit decreased. During the second phase, Company $\mathrm{C}$ had issues with foreign workers because some of them left home. The hire of new foreign workers was avoided as almost all of them lived in Samut Sakhon, which was a "red zone". Company C decided to operate overtime instead; thus, it had no lay-offs or recruitments in 2020. During the third phase, the cost of raw materials escalated from $10 \%$ to $500 \%$. The domestic demand was low even though the overseas demand was rising. For inventory management, Company $\mathrm{C}$ had a plan for at least one year. If some raw material was cheap, the company would buy large stock. No significant changes to the situation were observed during the overview.

\section{RESUltS OF THEMATIC ANALYSIS AND CROSS CASE ANALYSIS AND DISCUSSION}

This section discusses and compares the three cases to identify similarities and differences based on the key processes of the resilience cycle. Five key action stages (Scharte et al., 2014) are as follow:

- Prepare - taking specific actions in anticipation of potential situations, which involve making thorough preparations for disasters, especially early warning systems.

- Prevent - eliminating some adverse events by reducing the underlying risk factors.

- Protect - ensuring that physical and virtual protection systems operate flawlessly to minimise the negative impacts.

- Respond - providing the system for rapid, wellorganised, and effective disaster relief.

- Recover - bouncing back and learning relevant lessons to better prepare for future hazards or emerging events. 


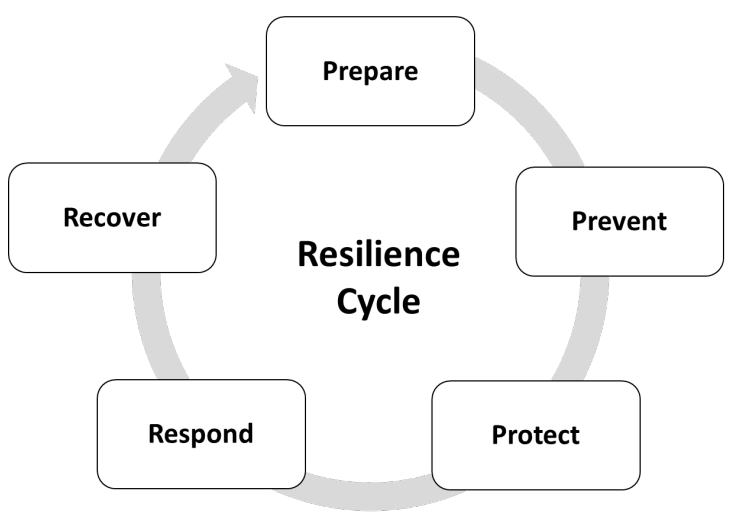

Fig. 1. Resilience Cycle

\subsection{IMPACT OF THE COVID-19 PANDEMIC ON AUTOMOTIVE COMPANIES IN THAILAND}

The production process was significantly affected, and the biggest concern was supply chain problems during the pandemic. Some difficulties were faced importing parts from abroad during the first phase lockdown. A more extended lead time was required for import, amounting to an increase of 14-15 days from China. Also, lot sizes increased for import products as containers were not available. However, the supply of domestic parts and products did not change much. For several months during the middle of 2020, no export was possible in some companies, resulting in a serious situation in the industry. Some had to close temporarily, and in the worst-case scenario, would have to leave the industry. Even though in 2021 the situation seems to be getting better, some pandemic-related issues persist.
As automotive products and parts are heavy, exports and imports are handled through shipment. Due to the rising demand, cargo ships and containers are scares even, so difficulties remain even once countries open the territory and start shipping products again. Besides, prices are growing, and advanced bookings are required. Some shipments are delayed, requiring the postponement of production and delivery. Companies must work harder than usual. As the second wave hit the province of Samut Sakhon, the automotive industry felt the impact straightaway. However, the "red zone" covers only three districts.

Many factories located near the shrimp market have to find a solution to prevent infection among employees. Employees living nearby have to be tested for the COVID-19 infection before returning to work; otherwise, those living in risky areas have to move and stay in accommodations provided by the company.

Tab. 1. Characteristics of case studies

\begin{tabular}{|c|c|c|c|}
\hline $\begin{array}{c}\text { CHARACTERISTICS } \\
\text { OF THE COMPANY }\end{array}$ & COMPANY A & CompanY B & CompanY C \\
\hline Established (year) & 1980 & No & No \\
\hline $\begin{array}{c}\text { A spin-off from a multinational } \\
\text { firm }\end{array}$ & Yes & Samut Sakhon & Pathum Thani \\
\hline $\begin{array}{c}\text { Current location } \\
\text { Capital structure }\end{array}$ & Pathum Thani & Joint Venture & Joint Venture \\
\hline
\end{tabular}




\begin{tabular}{|c|c|c|c|}
\hline Product & $\begin{array}{l}\text { Motorcycle bulb } \\
\text { Rear bulb } \\
\text { Auto bulb } \\
\text { Dies and moulds }\end{array}$ & $\begin{array}{c}\text { Trucks } \\
\text { 4x4 Eco Truck/ Multi-Purpose } \\
\text { Truck (MPT) } \\
\text { Pickup Truck Solutions, Steel } \\
\text { Canopy, and Accessories } \\
\text { Hydraulics } \\
\text { Axle } \\
\text { Spared Parts } \\
\text { Die } \\
\text { Jig and Checking Fixture } \\
\text { Press Steel Parts } \\
\text { Conveyor Belt Loaders Stan- } \\
\text { dard } \\
\text { Conveyor Belt Loaders with } \\
\text { Option } \\
\text { Baggage Cart } \\
\text { Pallet Dolly } \\
\text { Container Pallet Loader }\end{array}$ & $\begin{array}{l}\text { Plastic injection parts } \\
\text { Lamp and mirror parts } \\
\text { Metal standing parts } \\
\text { Coolant parts } \\
\text { Suspension parts } \\
\text { Engine and brake parts } \\
\text { Cable and hose }\end{array}$ \\
\hline Level in supply chain & Tier $1 / 2 / 3$ & Tier $1 / 2 / 3$ & Tier $1 / 2 / 3$ \\
\hline Customer & Both domestic and oversea & Both domestic and oversea & Both domestic and oversea \\
\hline Supplier & Both domestic and oversea & Both domestic and oversea & Both domestic and oversea \\
\hline Factory location & Pathum Thani and China & Samut Sakhon and China & Pathum Thani and India \\
\hline $\begin{array}{l}\text { Experience in handling a crisis } \\
\text { in the past }\end{array}$ & Thailand flood in 2011 & $\begin{array}{l}\text { The factory operated for more } \\
\text { than } 60 \text { years and faced many } \\
\text { crises, such as the Thailand } \\
\text { Flood in } 2011 \text { or the Thailand } \\
\text { Tom Yum Kung Crisis. }\end{array}$ & $\begin{array}{l}\text { Thailand Floods in } 2011 \text { but } \\
\text { did not mention in detail. }\end{array}$ \\
\hline Business Continuity Plan & Did not mention. & $\begin{array}{l}\text { They have been working on } \\
\text { auditing for } 30 \text { years. Move } \\
\text { the plant to the gateway to } \\
\text { be close to their customers } \\
\text { to reduce risk. Practice this } \\
\text { evacuation plan. }\end{array}$ & $\begin{array}{l}\text { BCP is available by technology, } \\
\text { enlarging the target and risk } \\
\text { management in several fields. }\end{array}$ \\
\hline
\end{tabular}


Tab. 2. Thematic analysis and cross-case studies

\begin{tabular}{|c|c|c|c|c|c|}
\hline RESILIENCE & THEME & CASE ANALYSIS FACTOR & COMPANY A & COMPANY B & COMPANY C \\
\hline $\begin{array}{l}\text { ㅇ } \\
\frac{0}{0} \\
\frac{\pi}{0} \\
\frac{0}{0} \\
\frac{0}{2} \\
-i \\
-i\end{array}$ & 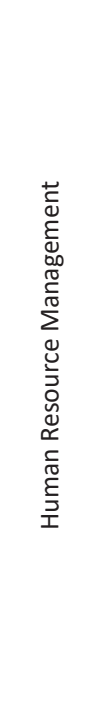 & $\begin{array}{l}\text { Employee tracking sys- } \\
\text { tem }\end{array}$ & $\begin{array}{l}\text { Telecommunication } \\
\text { Video conference } \\
\text { No, but employees not } \\
\text { allowed to go to the } \\
\text { high-risk areas } \\
\text { Concern about employ- } \\
\text { ees' mobility because } \\
\text { they are not working } \\
\text { from home if there is no } \\
\text { lockdown } \\
\text { Supporting COVID-19 } \\
\text { testing upon return from } \\
\text { a trip abroad and pre- } \\
\text { pare a space for them to } \\
\text { quarantine }\end{array}$ & $\begin{array}{l}\text { COVID-19 forced them } \\
\text { to change to digitisation. } \\
\text { Use their application to } \\
\text { communicate } \\
\text { No. Only monitoring } \\
\text { by asking employees } \\
\text { directly } \\
\text { Concern about employee } \\
\text { mobility because of } \\
\text { almost } 2000 \text { employees } \\
\text { and the COVID-19 infec- } \\
\text { tion outside the factory } \\
\text { as it is impossible to con- } \\
\text { trol where employees go } \\
\text { Support employees in } \\
\text { skills improvement, } \\
\text { including learning to use } \\
\text { technologies to be able } \\
\text { to work from home dur- } \\
\text { ing the pandemic }\end{array}$ & $\begin{array}{l}\text { Telecommunication } \\
\text { Video conference } \\
\text { Yes } \\
\text { Work overload due } \\
\text { to the lack of migrant } \\
\text { labour and concerns } \\
\text { about the outbreak from } \\
\text { employee dormitory/ } \\
\text { community } \\
\text { Support the COVID-19 } \\
\text { testing, no downsizing, } \\
\text { increased OT support, } \\
\text { employee skills training } \\
\text { and application at work }\end{array}$ \\
\hline 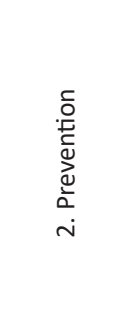 & 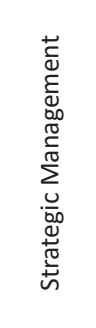 & Online for internal use & $\begin{array}{c}\text { The factory appointed } \\
\text { a responsible manager, } \\
\text { and it was a successful } \\
\text { decision }\end{array}$ & $\begin{array}{l}\text { The manager acted } \\
\text { fast and provided clear } \\
\text { regulations to be fol- } \\
\text { lowed consistently. The } \\
\text { manager was respected } \\
\text { and trusted } \\
\text { Yes }\end{array}$ & $\begin{array}{l}\text { Strong at information } \\
\text { technology, applying the } \\
\text { technology to eliminate } \\
\text { waste time processes } \\
\text { (lean operation), and } \\
\text { using technology to } \\
\text { survive, i.e., 3D printing } \\
\text { for B2C } \\
\text { No }\end{array}$ \\
\hline \multirow[t]{2}{*}{ 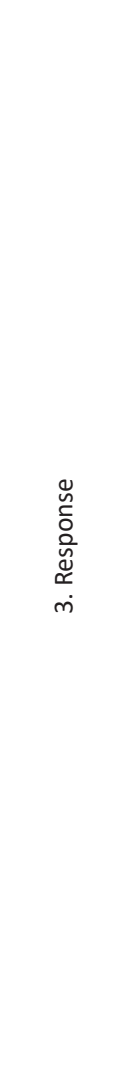 } & 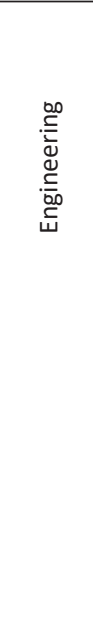 & $\begin{array}{l}\text { Introduction of new } \\
\text { technology } \\
\text { Product design }\end{array}$ & $\begin{array}{l}\text { Did not mention } \\
\text { Some employees design } \\
\text { products for customers }\end{array}$ & $\begin{array}{l}\text { Order suppliers online } \\
\text { and develop electric } \\
\text { vehicle technology } \\
\text { Has an R\&D department, } \\
\text { cooperates with govern- } \\
\text { ment organisations and } \\
\text { educational institutions. } \\
\text { Use drawings to discuss } \\
\text { via online meetings } \\
\text { Keyman still visits the } \\
\text { customers but at a re- } \\
\text { duced frequency from } 4 \\
\text { to } 2 \text { times/year }\end{array}$ & $\begin{array}{l}\text { Internal application for } \\
\text { tracking employees. } \\
\text { 3D Printing technology } \\
\text { R\&D uses CAD files as } \\
\text { the primary channel } \\
\text { between the company, } \\
\text { customer and supplier } \\
\text { Customer's employees } \\
\text { work in the firm to con- } \\
\text { duct QC methods and } \\
\text { verify by a certificate } \\
\text { from third parties in } \\
\text { Europe } \\
\text { Yes, from a customer }\end{array}$ \\
\hline & 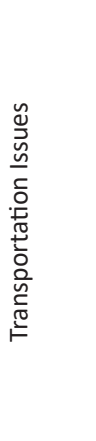 & $\begin{array}{l}\text { Import parts during the } \\
\text { pandemic }\end{array}$ & $\begin{array}{l}\text { Take a longer time to } \\
\text { arrive since there is no } \\
\text { container } \\
\text { Increased prices and } \\
\text { containers are difficult } \\
\text { to get }\end{array}$ & $\begin{array}{c}\text { No export } \\
\text { The long lead time for } \\
\text { import increased by } \\
\text { 14-15 days from China } \\
\text { and might cause delays. } \\
\text { The increased lot size for } \\
\text { import products } \\
\text { Increased prices and } \\
\text { containers are difficult } \\
\text { to get }\end{array}$ & $\begin{array}{c}\text { Export decreasing by } 11 \\
\% \text { but domestic growth } \\
\text { by } 7 \% \\
\text { Lack of importing from } \\
\text { China, using local sup- } \\
\text { pliers, the price is low } \\
\text { because the domestic } \\
\text { demand is low } \\
\text { Increased prices and } \\
\text { containers are difficult } \\
\text { to get }\end{array}$ \\
\hline
\end{tabular}




\begin{tabular}{|c|c|c|c|c|c|}
\hline 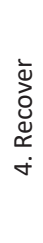 & $\frac{0}{n}$ & $\begin{array}{l}\text { COVID-19 effect on the } \\
\text { sale }\end{array}$ & $\begin{array}{l}\text { The sale is about } 40 \% \\
\text { lower than usual }\end{array}$ & $\begin{array}{l}\text { Sales recovered but } \\
\text { not fully to } 100 \% \text {. Less } \\
\text { overseas customers }\end{array}$ & $\begin{array}{l}\text { Sales increased because } \\
\text { many suppliers and } \\
\text { customers purchase } \\
\text { from this firm instead } \\
\text { of China. Suppliers in } \\
\text { China cannot export any } \\
\text { products }\end{array}$ \\
\hline $\begin{array}{l}\text { पू } \\
\stackrel{\Delta}{0} \\
\vdots \\
\dot{0} \\
\text { ம் }\end{array}$ & 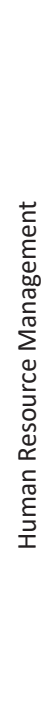 & Vaccination & $\begin{array}{l}\text { No, which is on the } \\
\text { interview date (December } \\
15,2020) \\
\text { The manufacturing } \\
\text { section still works on- } \\
\text { site but is divided into } \\
2 \text { groups and works in } \\
\text { shifts, the other employ- } \\
\text { ees work at different } \\
\text { times. } \\
\text { Very strict for tem- } \\
\text { perature checking and } \\
\text { zoning. } \\
\text { Allow work from home } \\
\text { for the back-office de- } \\
\text { partment, such as ac- } \\
\text { counting, marketing, etc. }\end{array}$ & $\begin{array}{l}\text { Yes. Some of the employ- } \\
\text { ees who live in Samut } \\
\text { Sakhon province have an } \\
\text { interview date (March } \\
\text { 31, 2021) } \\
\text { The manufacturing sec- } \\
\text { tion still works on-site. } \\
\text { Employees who live in } \\
\text { risky areas quarantine } \\
\text { at home and test for } \\
\text { COVID-19 before return- } \\
\text { ing to work. Allows work } \\
\text { from home for the back- } \\
\text { office department, such } \\
\text { as accounting, market- } \\
\text { ing, etc. }\end{array}$ & $\begin{array}{l}\text { No, which is on the } \\
\text { interview date (April 19, } \\
\text { 2021) } \\
\text { The manufacturing } \\
\text { section still works on- } \\
\text { site but is divided into } \\
2 \text { groups and works in } \\
\text { shifts, the other employ- } \\
\text { ees work at different } \\
\text { times. } \\
\text { Allows work from home } \\
\text { for the back-office de- } \\
\text { partment, such as ac- } \\
\text { counting, marketing, etc. } \\
\text { Very strict with tempera- } \\
\text { ture checking and zoning }\end{array}$ \\
\hline
\end{tabular}

\subsection{NEW NORMAL WITHIN AUTOMOTIVE BUSI- NESSES}

The COVID-19 outbreak is a new situation, which has not yet been brought under control. This unpredictable event requires massive changes in usual work routines. Business leaders have to act very fast to handle the effects. Managers have to be tasked with communicating to everyone consistently to understand the message in the same way. Clear rules and regulations have to be enforced in the company and correspond to the rules from the government, including social distancing, wearing of a face covering, and the disinfection of the workplace. All imported materials or parts have to be disinfected before shipping and once received, to get rid of possible infection. For safety, work at crowded floor areas had to be reorganised into shifts on-site, and more work had to be allowed from home. Regular handwashing was mandatory. For employees, travel to risky zones was prohibited with imposed disciplinary measures in the case of failure to comply. To ensure business operation, some employees had to be provided with accommodation and food due to the inability to return home to an area deemed risky. Although Thailand has fewer cases of infection com- pared to other countries, the strict policy continues. Employees will be monitored and screened before entering the factory for personal and public health safety. The Thai government policies in the shortterm strategies anticipate rescheduling of working hours and work-from-home schemes.

All case studies had clear restrictions for social distancing, quarantine, and travel restrictions. Thus, they can prevent and control the COVID-19 infection internally and become resilient manufacturers. The findings support the previous study by Rajak et al. (2021), stating that social distancing is important for sustainable initiatives in the supply chain during the COVID-19 pandemic. For supply chain resilience, the firms increased the inventory turnover ratio and recruited local firms as suppliers to prevent the supply shortage. These strategies of the case studies in Thailand can be confirmed by Belhadi et al. (2021), stating that localisation of supply sources is the best strategy to mitigate risks related to supply chain resilience during the coronavirus epidemic in the automotive industry. Moosavi and Hosseini (2021) found that extra inventory resulted in a higher resilience than a backup supplier. However, the companies require to absorb the greater cost. 


\subsection{TECHNOLOGY INVOLVEMENT DURING THE PANDEMIC}

When the COVID-19 pandemic affected the world and almost made it stop, the data exchange and dissemination were recognised as crucial processes in the healthcare sector and other fields, such as the economy, community, and industry. Many prevention strategies have been prompted by the emergence of the COVID-19 pandemic in the industry sector, e.g., transportation restrictions and lockdown. Technology is the key factor for new normal practices, especially Industry 4.0 technologies. Firstly, the communication with suppliers and customers changed from company visits to telecommunications using online meetings or assigning employees who stay in partner companies to conduct quality control or design new products. Secondly, the companies took the opportunity to enlarge their market by launching new services and purchasing new machines when the prices dropped. Thirdly, the traditional sale process (face-to-face) is changed to completely online. Some companies built their platform to accommodate online orders, which helped them to save costs and create opportunities in finding new customers. Fourthly, some companies developed a healthcare application to track employee health status and travel. New technologies implemented during the pandemic have changed business operations and production processes for the period of the current disruption and for post-COVID-19. Thus, the use of emerging technologies during disruptions can be considered a long-term response strategy. This outcome supports findings by Belhadi et al. (2021) that advanced Industry 4.0 technologies aim to reduce the COVID-19 disruptions in the automotive industry. In addition, the real-time information on various supply chain activities shared among stakeholders plays an essential role in overcoming the challenges of the COVID19 outbreak (Belhadi et al., 2021). The resilience practices using digital technologies confirmed the initial research by Ivanov et al. (2019) and Ralston and Blackhurst (2020), stating the aim of digital technologies to enhance supply chain resilience. Digital technologies, such as the Internet of Things (IoT), Big Data, and Digital Twin, improve high connectivity, accuracy, and transparency between supply chain stakeholders (Hofmann et al., 2019; Kamble \& Gunasekaran, 2020).

\subsection{TECHNOLOGY TRANSFER FROM SUPPLY CHAIN PARTNERS AND THE EXPERIENCES FROM PAST CRISIS EVENTS}

During the pandemic, the automotive industry was affected by a lack of remote working options. Manufacturing was nearly suspended at the beginning of the second quarter, and demand dropped, leading businesses to significant financial losses. Automobile firms must work hard to recover from the inactive manufacturing time as production gradually resumes. All the three firms of the case studies were Tier 1; they had transferred the technology and innovation from their partners. One of the partners was Toyota, which had transferred the production system to its customers. Each firm tried to apply and develop a production system. Since the companies had operated for more than twenty years, they faced crises, disasters, and other global events, e.g., Tom Yum Kung Financial Crisis in 1997 and Thailand Floods in 2011. However, the COVID-19 pandemic differs from natural disasters or human-made interruptions (Guan et al., 2020). The duration and magnitude of the coronavirus outbreak (the scope of the disruption's impact on related enterprises) are catastrophic compared to other experienced disruptions (Moosavi \& Hosseini, 2021). The knowledge and BCP transferred from partners were the fundamental measures in overcoming the risk related to the pandemic. This finding is supported by Belhadi et al. (2021), stating that collaboration among supply chain stakeholders aims to accelerate digital technology implementation and build a resilient manufacturing operation.

\subsection{MAJOR CONCERNS FOR THE PANDEMIC}

Human resources are the most important in the industry, and not the machines or capital. All three firms were concerned about the behaviour of their employee during the COVID-19 pandemic because almost all employees had no car and stayed in dormitories. Employees can be infected easily in the living environment, such as a market, dormitory, or other communal spaces. In the case of a large number of infected employees, the entire area is treated as a COVID-19 cluster and requires a quarantine of 14 days. In addition, the firms required their staff to avoid risk, and the recruiting process was stricter for screening new employees. Migrant employees from 
"red zones" were not allowed to apply or arrive for an on-site interview. Some companies had to stop the recruiting process for the COVID-19 pandemic or conduct it online. These processes of the "new normal" are consistent with short-term strategies of the Thai government, as mentioned in the introduction (Centre for COVID-19 Situation Administration, 2020; Department of Disease Control, 2021; Federation of Thai Industries, 2020).

\section{CONCLUSIONS}

The COVID-19 pandemic disrupted the automotive industry and supply chain management. Keys to surviving the COVID-19 disruption have three components, i.e., leadership, experience, and technology. These three keys result in preparation for similar cases, e.g., putting Business Continuity Plans and/or risk management plans in place. Leadership is the most important factor in foresing the future and opportunities, helping the company to turn threats into success. During the COVID-19 pandemic, companies encounter the "new normal" that forces them to rearrange business operations as well as improve production processes. A good example from the case studies was investments in new technologies to improve production processes and enhance productivity. Additionally, companies use the advantage to train employees by upskilling, reskilling and providing new skills. The employees understand the need for technologies and have less resistance towards the adoption of new technologies.

Another example is that some firms invested in creating the COVID-19 control centre to provide consistent information and apply strategies for containing the spread of the COVID-19 infection. Applications can be used to track and update the health status of infected employees.

Technology helps to create automation systems and share different data inside and outside the company. Upgraded telecommunication is one of the strategies that almost every organisation used during this crisis. Even once the COVID-19 pandemic is over, computing technologies will continue to play a major role, especially in reassessing policy responses. Therefore, it is important to support stakeholders in the implementation and improvement of strategies to prepare for similar potential significant disruptive events in the future.

Finally, experience in handling the emerging situation is of utmost importance. After the second and third wave of the infection, almost all large companies had their Business Continuity Plan designed to prevent and prepare for similar cases that might occur in the future. Thus, the "new normal" arising from the COVID-19 pandemic is perceived as experiences comparable to previous cases, e.g., Avian Influenza (Bird Flu), the Swine Flu Pandemic in 2009, Thailand Floods in 2011. These emerging situations force companies to prepare Business Continuity Plans (BCP), which provide an advantage in terms of resilience for the production processes and supply chain management.

\section{ACKNOWLEDGEMENTS}

The authors would like to express their gratitude to Ms Rusameekhair Wongchadakul, Deputy Director (Executive), Ms Jeeraphan Suktavee, Safety and Environment Manager, Ms Marisa Chukittipong, Human Resource Manager, and Ms Piyaporn Thongprasert Client Service of Environment \& Energy Section from Thai Stanley PLC. Mr Anan Piammanustham, General Manager Human Capital Development and Organization Department, $\mathrm{Mr}$ Wanchai Suvarnmanee, Affair and Employee Relationship Manager from Sammitr Motors Manufacturing PLC., Dr Saruda Siripatpricha, Sustainability Manager and Ms Sutima Sukboon from Fortune Industry Parts PLC.

This research is fully supported by the Center of Excellence in Logistics and Supply Chain Systems Engineering and Technology (CoE LogEn), Sirindhorn International Institute of Technology, Thammasat University.

The publication of the article for the 11th International Conference on Engineering, Project, and Production Management - EPPM2021 was financed within the framework of contract no. DNK/ SN/465770/2020 by the Ministry of Science and Higher Education within the "Excellent Science" programme.

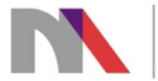

Ministry of Science and Higher Education Republic of Poland

\section{LITERATURE}

Belhadi, A., Kamble, S., Jabbour, C. J. C., Gunasekaran, A., Ndubisi, N. O., \& Venkatesh, M. (2021). Manufacturing and service supply chain resilience to the COVID-19 outbreak: Lessons learned from the 
automobile and airline industries. Technological Forecasting and Social Change, 163, 120447. doi: 10.1016/j.techfore.2020.120447

Brem, A., Viardot, E., \& Nylund, P. A. (2021). Implications of the coronavirus (COVID-19) outbreak for innovation: Which technologies will improve our lives? Technological Forecasting and Social Change, 163, 120451. doi: 10.1016/j.techfore.2020.120451

Cai, M., \& Luo, J. (2020). Influence of COVID-19 on Manufacturing Industry and Corresponding Countermeasures from Supply Chain Perspective. Journal of Shanghai Jiaotong University (Science), 25(4), 409416. doi: 10.1007/s12204-020-2206-Z

Department of Disease Control. (2021). The COVID-19 precautionary, prevention, and control measures for entrepreneurs. Retrieved from https://ddc.moph.go. th/viralpneumonia/file/int_operator/int_operator23_050164.pdf

Francis, J.R. (2020). COVID-19: Implications for Supply Chain Management. Frontiers of Health Services Management, 37(1), 33-38. doi: 10.1097/ hap.0000000000000092

Gallup. (2020). How Leaders Are Responding to COVID19 Workplace Disruption. Retrieved from https:// www.gallup.com/workplace/307622/leadersresponding-covid-workplace-disruption.aspx.

Giones, F., Brem, A., Pollack, J. M., Michaelis, T. L., Klyver, K., \& Brinckmann, J. (2020). Revising entrepreneurial action in response to exogenous shocks: Considering the COVID-19 pandemic. Journal of Business Venturing Insights, 14, e00186. doi: 10.1016/j. jbvi.2020.e00186

Guan, D., Wang, D., Hallegatte, S., Davis, S. J., Huo, J., Li, S., Bai, Y., Lei, T., Xue, Q., Coffman, D., Cheng, D., Chen, P., Liang, X., Xu, B., Lu, X., Wang, S., Hubacek, K., \& Gong, P. (2020). Global supply-chain effects of COVID-19 control measures. Nature Human Behaviour, 4(6), 577-587. doi: 10.1038/s41562-020-0896-8

He, W., Zhang, Z. J., \& Li, W. (2021). Information technology solutions, challenges, and suggestions for tackling the COVID-19 pandemic. International Journal of Information Management, 57, 102287. doi: 10.1016/j.ijinfomgt.2020.102287

Heidenreich, S., \& Talke, K. (2020). Consequences of mandated usage of innovations in organizations: developing an innovation decision model of symbolic and forced adoption. AMS Review, 10, 279-298. doi: 10.1007/s13162-020-00164-X

Hofmann, E., Sternberg, H., Chen, H., Pflaum, A., \& Prockl, G. (2019). Supply chain management and Industry 4.0: conducting research in the digital age. International Journal of Physical Distribution \& Logistics Management, 49(10), 945-955. doi: 10.1108/IJPDLM-11-2019-399

Ishida, S. (2020). Perspectives on Supply Chain Management in a Pandemic and the Post-COVID-19 Era. IEEE Engineering Management Review, 48(3), 146152. doi: $10.1109 / \mathrm{emr} .2020 .3016350$

Ivanov, D., Dolgui, A., \& Sokolov, B. (2019). The impact of digital technology and Industry 4.0 on the ripple effect and supply chain risk analytics. International Journal of Production Research, 57(3), 829-846. doi: 10.1080/00207543.2018.1488086
Kamble, S.S., \& Gunasekaran, A. (2020). Big data-driven supply chain performance measurement system: a review and framework for implementation. International Journal of Production Research, 58(1), 65-86. doi: 10.1080/00207543.2019.1630770

Lai, C. C., Shih, T. P., Ko, W. C., Tang, H. J., \& Hsueh, P. R. (2020). Severe acute respiratory syndrome coronavirus 2 (SARS-CoV-2) and coronavirus disease-2019 (COVID-19): The epidemic and the challenges. International Journal of Antimicrobial Agents, 55(3), 105924. doi: 10.1016/j.ijantimicag.2020.105924

Lombardi, S., Pina E Cunha, M., \& Giustiniano, L. (2021). Improvising resilience: The unfolding of resilient leadership in COVID-19 times. International Journal of Hospitality Management, 95, 102904. doi: 10.1016/j. ijhm.2021.102904

Manuj, I., \& Mentzer, J. T. (2008). Global supply chain risk management. Journal of Business Logistics, 29(1), 133-155. doi: 10.1002/j.2158-1592.2008.tb00072.x

Margherita, A., \& Heikkilä, M. (2021). Business Continuity in the COVID-19 Emergency: A Framework of Actions Undertaken by World-Leading Companies. Business Horizons.

Moosavi, J., \& Hosseini, S. (2021). Simulation-based assessment of supply chain resilience with consideration of recovery strategies in the COVID-19 pandemic context. Computers \& Industrial Engineering, 160, 107593. doi: 10.1016/j.cie.2021.107593

Nakamura, H., \& Managi, S. (2020). Airport risk of importation and exportation of the COVID-19 pandemic. Transport Policy, 96, 40-47.

Namwat, C., Suphanchaimat, R., Nittayasoot, N., \& Iamsirithaworn, S. (2020). Thailand's response against coronavirus disease 2019: challenges and lessons learned. OSIR, 13(1), 33-37.

Narayanamurthy, G., \& Tortorella, G. (2021). Impact of COVID-19 outbreak on employee performance moderating role of industry 4.0 base technologies. International Journal of Production Economics, 234, 108075. doi: 10.1016/j.ijpe.2021.108075

Peleg, K., Bodas, M., Hertelendy, A. J., \& Kirsch, T. D. (2021). The COVID-19 pandemic challenge to the All-Hazards Approach for disaster planning. International Journal of Disaster Risk Reduction, 55, 102103. doi: 10.1016/j.ijdrr.2021.102103

Rajak, S., Mathiyazhagan, K., Agarwal, V., Sivakumar, K., Kumar, V., \& Appolloni, A. (2021). Issues and analysis of critical success factors for the sustainable initiatives in the supply chain during COVID-19 pandemic outbreak in India: A case study. Research in Transportation Economics, 101114. doi: 10.1016/j.retrec.2021. 101114

Ralston, P., \& Blackhurst, J. (2020). Industry 4.0 and resilience in the supply chain: a driver of capability enhancement or capability loss? International Journal of Production Research, 58(16), 5006-5019. doi: 10.1080/00207543.2020.1736724

Scharte, B., Hiller, D., Leismann, T., \& Thoma, K. (2014). Introduction. In K. Thoma (Ed.), Resilien Tech. Resilience by design: a strategy for the technology issues of the future (acatech STUDY) (pp. 9-17). München, Germany: Herbert Utz Verlag. 
Thailand Automotive Institute (2021b). Automotive Industry Statistics \& Trends of June 2021. Retrieved from https://data.thaiauto.or.th/auto/articles-th/autosummary-th/148-auto-industry-status-monthly/ 9831-สภาวะอุตสาหกรรมยานยนต์-รายเดือน-พฤษภาคม- $2564 . \mathrm{html}$

Thailand Automotive Institute. (2021a). Automotive Industry Statistics of Year 2020 \& Trends of Year 202. Retrieved from https://data.thaiauto.or.th/auto/articles-th/auto-summary-th/150-auto-industry-statusyearly/9692-summary-yearly-2565.html

The Centre for COVID-19 Situation Administration. (2020). The manual guideline of relief measures for business activities to prevent the COVID-19 pandemic: Business activities group 2. Retrieved from https://ddc.moph.go.th/viralpneumonia/file/guidelines/guideline_green_covid19.pdf

The Federation of Thai Industries. (2020). The guidelines of COVID-19 prevention for industrial sector. Retrieved from http://www.fti-rayong.com/wp-content/uploads/2020/12/แนวปฏิบัติ-8-กลุ่มอุตสาหกรรมยึงยวด_ FTI_JUNE.pdf

The National Academies. (2012). Disaster Resilience. A National Imperative. Washington, D.C.

Tortorella, G., Narayanamurthy, G., Godinho Filho, M., Portioli Staudacher, A., \& Mac Cawley, A. F. (2021). Pandemic's effect on the relationship between lean implementation and service performance. Journal of Service Theory and Practice, 31(2), 203-224.

Yau, B., Vijh, R., Prairie, J., McKee, G., \& Schwandt, M. (2021). Lived experiences of frontline workers and leaders during COVID-19 outbreaks in long-term care: A qualitative study. American Journal of Infection Control, 49(8), 978-984. doi: 10.1016/j. ajic.2021.03.006

Yoga Irsyadillah, N., \& Dadang, S. (2020). A Literature Review of Supply Chain Risk Management in Automotive Industry. Journal of Modern Manufacturing Systems and Technology, 4(2), 12-22. doi: 10.15282/ jmmst.v4i2.5020

Yongpisanphob, W. (2020). Industry Outlook 2020-2022: Automobile Industry. Krungsri Research. Retrieved from https://www.krungsri.com/en/research/industry/industry-outlook/Hi-tech-Industries/Automobiles/IO/io-automobile-20

Yoo, S., \& Managi, S. (2020). Global mortality benefits of COVID-19 action. Technological Forecasting and Social Change, 160, 120231. doi: 10.1016/j.techfore.2020.120231 